\title{
Nodular heterotopia: a rare finding in patients with epilepsy and SCN1A mutation
}

Heterotopia nodular: um achado raro em pacientes com epilepsia por mutação no gene SCN1A

Matheus Rocha Pereira KLETTENBERG', Victor Alves RODRIGUES', Diógenes Diego de Carvalho BISPO', Paulo Emidio Lobão CUNHA', Lisiane Seguti FERREIRA ${ }^{1}$

A 25-year-old man had started febrile seizures from 6 months of age and developed important neurodevelopmental delay. At four years presented with status epilepticus and sequentially with refractory epilepsy. He presents with motor delay, behavior disorder and absent expressive language. Brain MRI showed periventricular nodular heterotopias (Figures 1 and 2). The Next Generation Sequencing (NGS) came with a rare frameshift mutation in heterozygosis for SCN1A gene.

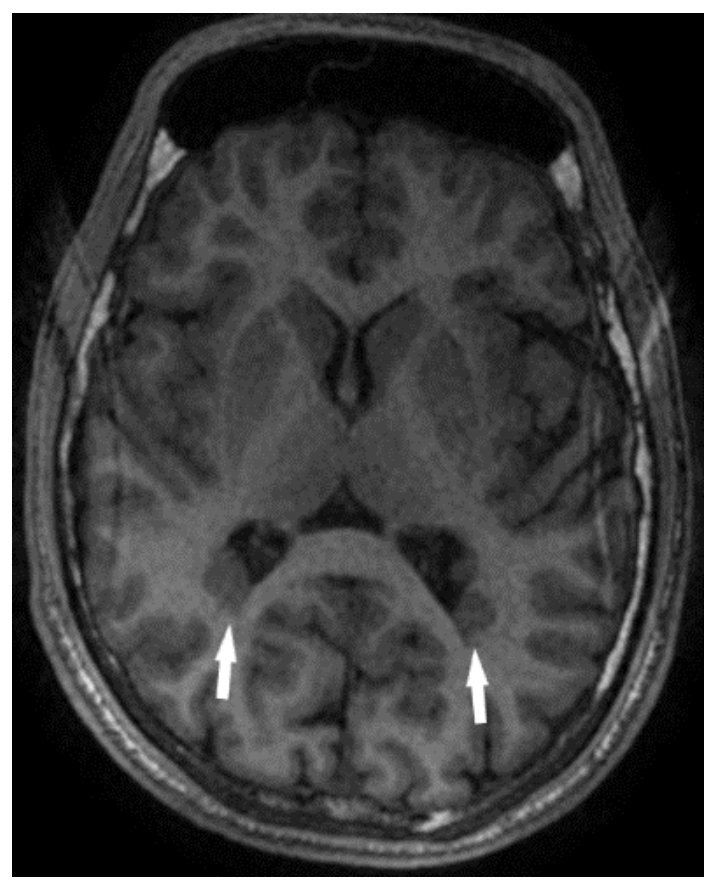

Figure 1. Axial T1WI with nodules of grey matter in the trigones of the lateral ventricles, and normal nuclei of deep gray matter.
The presence of periventricular heterotopias in association with SCN1A mutation is rare $^{1}$. In literature, we found only two cases reported, being it the most common finding in patients with Filamin A gene (FLNA) ${ }^{1,2}$. The CNS anomalies more common in SCN1A mutation are cortical atrophy, cerebellar atrophy, white matter hyperintensity, ventricular enlargement, hippocampal sclerosis, or cortical dysplasia ${ }^{3,4}$.

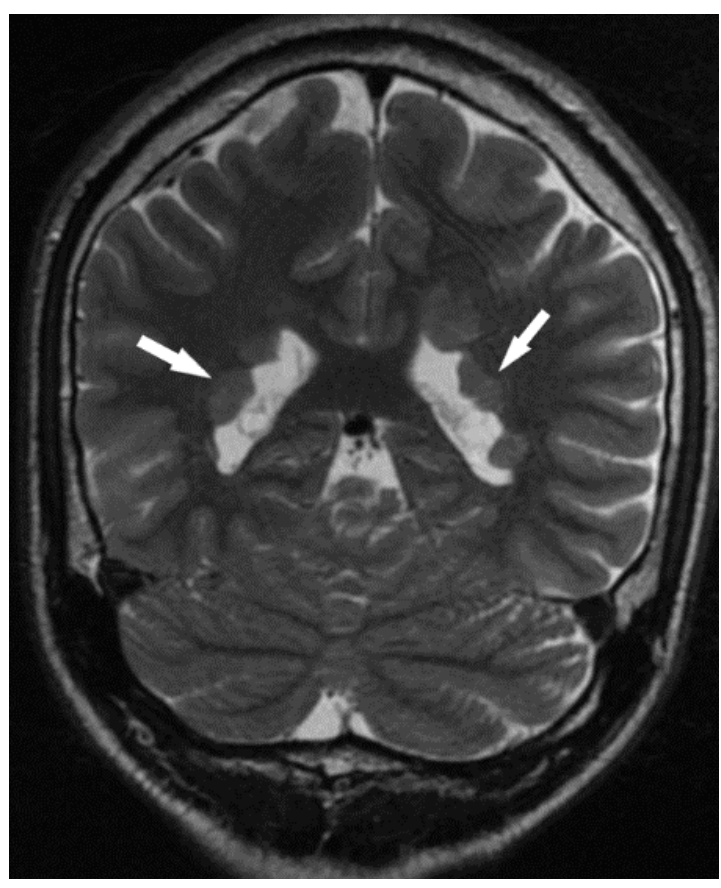

Figure 2. Coronal T2WI with nodules of grey matter in the trigones of the lateral ventricles.

\footnotetext{
'Universidade de Brasília, Faculdade de Medicina, Brasília DF, Brazil.

MRPK (D) https://orcid.org/0000-0001-5444-7404;VAR (D) https://orcid.org/0000-0001-8606-6809; DDCB (D) https://orcid.org/0000-0001-6660-2766; PELC (D) https://orcid.org/0000-0002-0795-6780; LSF (1D https://orcid.org/0000-0001-7037-1585
}

Correspondence: Lisiane Seguti Ferreira; Email: lisianeseguti@gmail.com.

Conflict of interest: There is no conflict of interest to declare.

Authors' contributions: MRPK: article writer and study designer; VAR: data collection; DCB: analysis and interpretation of data; PELC: critical revision; LSF: approval of the final version.

Received on March 03, 2021; Received in its final form on April 04, 2021; Accepted on April 11, 2021. 


\section{References}

1. Barba C, Parrini E, Coras R, Galuppi A, Craiu D, Kluger G, et al. Co-occurring malformations of cortical development and SCN1A gene mutations. Epilepsia. 2014 Jul;55(7):1009-19. https://doi.org/10.1111/epi.12658

2. Liu W, Yan B, An D, Xiao J, Hu F, Zhou D. Sporadic periventricular nodular heterotopia: Classification, phenotype and correlation with Filamin A mutations. Epilepsy Res. 2017 Jul;133:33-40. https://doi. org/10.1016/j.eplepsyres.2017.03.005
3. Lee YJ, Yum MS, Kim MJ, Shim WH, Yoon HM, Yoo IH, et al. Largescale structural alteration of brain in epileptic children with SCN1A mutation. Neurolmage Clin. 2017;15:594-600. https://doi. org/10.1016/j.nicl.2017.06.002

4. Guerrini R, Striano P, Catarino C, Sisodiya SM. Neuroimaging and neuropathology of Dravet Syndrome. Epilepsia. 2011 Apr;52 Suppl 2:30-4. https://doi.org/10.1111/j.1528-1167.2011.02998.x 